\title{
Janus' Voice: Religious Leaders, Framing, and Riots in Kano
}

\author{
David Ehrhardt ${ }^{1}$
}

Published online: 14 September 2016

(C) The Author(s) 2016. This article is published with open access at Springerlink.com

\begin{abstract}
This article analyses the role of religious leaders in collective violence in Kano, the major urban centre in northern Nigeria. It compares two episodes of collective action in the city - the violent 'Plateau riots' in 2004 and the non-violent 'cartoon protests' in 2006 - to explore the role of religious leaders in the variation in violence between the two events. The core argument is that the ways in which Islamic and Christian preachers framed the triggering events for these cases facilitated different forms of mobilisation and enemy identification in response. In 2004, the interpretation of violence in Plateau State through the 'Christiansversus-Muslims' frame allowed for mobilisation within Kano's Christian and Muslim communities as well as for the identification of local Christians as enemies. In 2006, in contrast, the infamous Danish cartoons were actively framed as part of the global struggle between faithful Nigerians and nonreligious Westerners, facilitating non-violent mobilisation across Christian-Muslim boundaries. Thus, the divergent discursive strategies employed by religious leaders are likely to have contributed to violent escalation in 2004 and to peaceful mobilisation in 2006. At the same time, however, the article emphasises the interaction of discursive framing with other factors, such as the role of security forces and the inextricable connections between religious and political authorities in Kano. The article is based on mixed-methods data collected in Kano between 2006 and 2012, including perceptions survey data, semi-structured interviews, and newspaper articles.
\end{abstract}

Keywords Riots $\cdot$ Religious leaders $\cdot$ Nigeria $\cdot$ Discursive framing $\cdot$ Collective violence Conflict resolution

David Ehrhardt

d.w.1.ehrhardt@luc.leidenuniv.nl

1 Leiden University College, Anna van Buerenplein 301, 2595DG Den Haag, The Netherlands 


\section{Introduction: violent conflict in northern Nigeria}

Since Nigeria's return to democracy in 1999, Human Rights Watch estimates that the country has witnessed the deaths of over 20,000 people in inter-communal, political, and religious violence (Human Rights Watch 2013, 2014, 2015). Much of this violence is locally rooted and therefore varies greatly in intensity, scope, context, and motivation across the country - from kidnappings in the Niger Delta to religiously inspired killings by Boko Haram. ${ }^{1}$ But the figure alone-20,000 - indicates the seriousness of the challenge that collective violence poses to the stability of Nigerian society. Not only does it harm the victims, but it also breeds distrust and grievance between the country's ethnic and religious communities and further weakens its fragile political and economic institutions. As such, collective violence ${ }^{2}$ destabilises Nigerian politics and thwarts the entrepreneurial efforts of ordinary Nigerians in search of economic prosperity.

Even before the rise of Boko Haram, northern cities like Kano were notorious for occasionally erupting into riotous violence-from the anti-Igbo riots in the 1950s to the anti-establishment violence in response to the 2011 presidential elections. These riots are the subject of this article. More specifically, the article explores the role of religious leaders in the production of these riots (Brass 2003), focusing, in particular, on the detailed mechanisms through which these leaders use their influence. Because while there is considerable policy-oriented optimism about the potential of religious leaders to shape collective violence (United States Institute for Peace (USIP) n.d.), for good or ill (Sisk 2011), there is insufficient systematic empirical material to understand the mechanisms behind this potential. Through a comparative case study of two episodes of collective action in Kano - the violent 'Plateau riots' of 2004 and the (surprisingly) non-violent 'cartoon protests' of 2006 - this article will explore the workings of one such mechanism: the way in which religious leaders can affect the discursive framing of triggering events and thus facilitate some forms of collective action over others.

The article builds on mixed-methods field research conducted between 2006 and 2012 in metropolitan Kano, northern Nigeria's largest city. Kano is a useful place to study the dynamics of religious authority and violence. With a population of over three million, the city has a long-standing reputation as the economic hub of northern Nigeria. Moreover, religion is highly salient, as a source of identification, faith, and political ideology; religious leaders, as a consequence, have important positions of authority in Kano society. And while it is a Muslim-majority city, Kano has a long history of trade, immigration, and diversity and continues to host a range of ethnic, religious, and other social groups. In particular, the city is home to a substantial minority of Christians, many of whom have ethnic origins in the south of Nigeria. Mostly, this diversity does not hinder cordial interactions across religious boundaries-

\footnotetext{
${ }^{1}$ Boko Haram, or Jamä'at Ahl as-Sunnah lid-da'wa wal-Jihād in full, is a violent organisation operating from Borno State in the northeast of Nigeria. Although its aims have been fluid and diffuse, the organisation has claimed responsibility for many deadly attacks in northern Nigeria since 2009. In Kano, the first major attack occurred on January 2012, when several coordinated bomb attacks killed more than 150 people. Regardless of recent defeats by the Nigerian armed forces, Boko Haram continues to constitute a serious challenge to Nigeria's security. The case of violence analysed in this article, however, preceded its rise to prominence and is an expression of different cleavages and conflicts prevalent in Nigeria's north, such as those revolving around Christian-Muslim competition.

${ }^{2}$ Collective violence is defined as group interactions in which members of different groups aim to harm each other or each other's property (Miall et al. 1999, pp. 63-64; Reimann 2004, p. 7).
} 
but the city has also seen more than its fair share of violence between members of different religious groups.

Methodologically, the article is exploratory and combines the logic of a most-similar comparative design with that of within-case process tracing, with the 2004 riots and 2006 peaceful protests in Kano as its two cases (George and Bennett 2005). Because these cases occurred in the same city in quite close succession, most important contextual variables can be assumed to have remained constant. On this basis, the case studies will suggest that discursive framing helps to explain the variation in violence between them. Within the cases then, process tracing will be used to identify the role of religious leaders in the dynamic production of the two episodes of collective action and demonstrate the mechanics of discursive framing in Kano. Various types of information will be used: a large-N perceptions survey, ${ }^{3}$ semi-structured interviews with key informants and stakeholders, ${ }^{4}$ newspaper articles, and the existing secondary literature on northern Nigeria.

Subsequent sections will proceed by examining some of the existing explanations of Kano's riots and positioning the article within the wider literature, before discussing religious competition in Kano and outlining the role of religious leadership in the two case study events.

\section{The role of religious leaders in 'religious' riots}

Riots, one of many forms of collective violence, often seem irrational in their sudden destructive intensity. Perhaps partly as a result, analysts use analytical adjectives to classify and implicitly explain such violence as spontaneous explosions of 'communal', 'ethnic', 'political', and of course, religious tensions. At least since the 1990s, violence in Kano has predominantly been described as religious, with the implication that religious beliefs or differences are deemed to be the root cause of the violence. However, while there are obvious religious connotations to their violence, riots are also inherently messy affairs that involve a range of actors with a range of different motivations. So while religious differences appear to play a role in the dramatic productions of riots (Brass 2003), it remains to be decided to what extent they are in fact a cause for their occurrence. This section reviews existing explanations of riot violence in northern Nigeria to tease out the role of, first, religion and, second, religious

\footnotetext{
${ }^{3}$ The perceptions survey is adapted from the one used by the Centre for Research on Inequality, Human Security and Ethnicity (CRISE) at the Department for International Development (Oxford). The Kano survey was administered to 420 individuals in four neighbourhoods of metropolitan Kano (Old City, Sabon Gari, Naibawa, and Badawa). These neighbourhoods were selected in order to ensure the representation of the widest possible range of religious and ethnic groups in the sample (i.e. these neighbourhoods comprise homogeneous 'native', homogeneous 'settler', mixed middle class, and mixed working class communities, respectively). Individual respondents were selected through random walking patterns and the random selection of respondents from lists of household members. Variations on this perceptions survey have been administered in various other places in and beyond Nigeria; for more details on the survey results, see Stewart (2008) and the papers at http://www.qeh.ox.ac.uk/research/research-networks/crise-network.

${ }^{4}$ The author conducted these interviews in several periods of fieldwork between 2006 and 2012. Respondents were selected purposefully, as key informants and/or stakeholders in Kano's processes of violence and conflict resolution, and the interviews included religious and traditional rulers, state officials, NGO workers, and others. Details of each of the cited interviews are given in footnotes, taking into account the respondents' preferences about anonymity.
} 
leaders. It will argue that one of the main functions of religious leaders in collective action centres on discursive framing: choosing how to frame, and make sense of, external events and thus facilitating certain forms of collective action over others.

\section{Religious riots in northern Nigeria}

While the focus of this article is on the role of religious leaders in the production of riots, there are of course many explanations for riotous violence that do not explicitly consider religion. Economic explanations, for example, highlight the importance of youth unemployment and the resulting pool of potential rioters (e.g. the almajirai or Quranic students) (Alkali 2009; Hoechner 2013) or of the grievances resulting from economic and other horizontal inequalities (Stewart 2008). Similarly, political explanations often focus on the violence-inducing incentives of Nigeria's neo-patrimonial political system (Allen 1999; Omeje 2006; North et al. 2009) or the lack of capacity of Nigerian security forces in managing riots (or even their complicity in particular episodes of violence) (Human Rights Watch 2005; Amnesty International 2015a). These analyses are essential to our understanding of Kano's riots; however, they create little analytical leverage to identify the influence of religious leaders. To this end, we need a better understanding of the relationships between religion and violent riots, which can, with some justifiable simplification, be conceptualised as essentialist, idealist, and instrumentalist (cf. Varshney 2007).

Essentialist explanations of violence identify people's primordial connections to religious groups and beliefs and their corresponding incompatibilities with others, as the cause for their violent behaviour. Idealist explanations, in contrast, sever the primordial connection between the individual and her beliefs and identify the content of certain religious beliefs as the cause for violence (Juergensmeyer 2001; Kippenberg and McNeil 2011). It is sometimes difficult to distinguish between the two approaches in empirical analyses, but where the validity of essentialism has been challenged by constructivist approaches to violence and religion, idealism has proven more compatible and, perhaps as a result, more resilient. Instrumentalist explanations, finally, suggest that violence is the result of the strategic use of religion by both elites and non-elites (Fearon and Laitin 2000).

Most authors writing on northern Nigerian violence employ elements from several of these theoretical approaches in explicitly multi-causal narratives. Falola (1998), for example, adopts an "eclectic framework" that combines a structural analysis of political instability, diversity, poverty, and modernisation (ibid, pp. 12-13) with a more instrumentalist approach in which, he argues, "the issue of religious dominance" is the key driver (ibid, p. 2). Last (2007) also combines different approaches as he emphasises population growth and youth unemployment in a context of increasingly unrestrained politic-economic competition and "political anxiety" among northern Muslims about the maintenance of dar-al Islam. Religious riots, in Last's analysis, can be seen as expressions of the resulting tensions. However, at the same time, he questions the religious nature of riot violence, moving into more instrumentalist territory: "to attack [a church or mosque] may not be primarily an attack on the others' 'faith" but rather on "ordinary people, competitors" (ibid, p. 614). This point resonates with analyses of riots in other parts of the region as well as the 2004 Plateau riots analysed below (Cooper 2006).

Focusing on Jos, then, Higazi's (2011) narrative highlights structural factors such as political competition and patterns of ethnic exclusion, but argues that locally contingent 
variables are also necessary to understand specific incidents of violence on the Plateau. Mustapha (2014) finally brings doctrinal disputes into the mix, highlighting the idealist dimensions of northern Nigerian violence alongside patterns of instrumentalisation. For what Kane (2003) has referred to as the fragmentation of religious authority has in some cases fuelled conflict (Mustapha 2014, p. 199). When and where this happened, it was partly due to substantive doctrinal disagreements, but particularly to their interaction with wider social processes, including

party politics mixing up with the Qadiriyya-Tijaniyya dispute in the 1940s, the doctrinal intolerance of Izala and its efforts to consolidate a Muslim hold on the state from the 1970s, the politicisation of Muslim-Christian relations by both sides from the 1980s, and the underlying frustration and desperation of the poor and marginalised, faced with economic crises, structural adjustment policies, and the lack of an effective political platform for articulating their concerns (Mustapha 2014, p. 208).

There is thus a tradition of multi-causal analyses of cases in the literature on northern Nigerian violence, which are to an extent context-specific but share an emphasis on structural, precipitating factors such as unrestrained political competition, poverty, (group) marginalisation, and rapid population growth. This article takes the importance of such precipitating factors as a starting point for a more dynamic comparative approach, aiming to explore how two comparable external 'shocks' can lead to very different forms of collective action even though their structural context (Kano in 2004 and 2006) has not changed significantly. To explain such variation, the paper borrows from political science and social movements literature on collective action, with discursive framing as its central concept: the discursive act of collectively making sense of new and unexpected information, such as triggering events, through the filters of existing mental models, identity cleavages, fields of contention, or other heuristic devices (Gentner and Stevens 1983; McAdam and Tarrow 2000; Snow 2004; Kendhammer 2016).

The argument, then, is that collective violence requires framing in order to translate triggering events and structural precipitants of violence into 'scripts' for action, a sense of opportunity and justification, and feasible channels of mobilisation and enemy identification (Gamson 1992; Gamson and Meyer 1996; Horowitz 2000, 2002; Kippenberg and McNeil 2011). Fields of contention, or identity cleavages, are particularly effective discursive frames to mobilise for violence because they supply sets of group categories and "socially constructed [...] adversarial relationships" between them (McAdam and Tarrow 2000, p. 149). In situations where collective violence is facilitated by precipitating factors, some cleavages can enable people to identify, and mobilise against, certain 'enemies' as legitimate targets of violent action. Other cleavages, in contrast, can similarly facilitate non-violence. The selection of discursive frames, significant because of its potential effect on violence, then depends on the salience and potential for resonance of particular cleavages as well as the framing decisions of influential elites, including religious leaders in the case of Kano.

This argument is partly instrumentalist, in that it includes the strategic agency of individuals in processes of framing and mobilisation, and partly idealist, by recognising that the content and salience of identity cleavages matter. Of course, this a rather 'thin' 
version of idealism, falling short of 'thicker' views that argue, for example, how religious and cosmic symbolism can be used to justify violence (Juergensmeyer 2001) or how some religious beliefs make their believers more violent than others (Hirsi Ali 2015). Such 'thick' idealist analyses are valuable as interpretive accounts of the religious meanings that perpetrators give to their violent acts, but problems of measurement and generalisation restrict their usefulness in comparative and causal analysis.

\section{Religious leaders and religious riots}

We will now consider how religious leaders fit into this framework. Religious leaders will be defined simply as individuals who have a form of legitimate power over a social group or community that defines itself in religious terms (Dahrendorf 1958, p. 176; Lukes 2005, p. 35). Moreover, they rely at least in part on charisma ${ }^{5}$ to legitimise their power (Weber (1978 [1925]). In Kano, such charisma can take various forms, but mostly, it relies on a measure of 'closeness to God', for example baraka in Sufi terminology or Ase among the Christian Pentecostal groups. These terms denote spiritual grace and charisma but have also come to imply a measure of political and economic power (Cruise O’Brien 1975, p. 10; Marshall 1993, p. 226).

Existing analyses of religious leadership in violent conflict suggest different potential roles in the production and prevention of riots (Gopin 1997). Scholars in the tradition of conflict resolution commonly view the role of religious leaders in terms of third-party interventions and mediation (Bercovitch and Rubin 2002; Berridge 2002; Bercovitch and Kadayifci-Orellana 2009; Brewer et al. 2014). In the literature on northern Nigeria, this approach is most clearly represented by the works on faith-based, non-governmental organisations and their mediation and reconciliation activities (Smock 2006; Haynes 2009). Paden (2005) argues along similar lines, suggesting that many civic cultures in Nigeria "are predisposed to conflict resolution mechanisms, both within and between cultures" (p. 205). Within the Emirate civic culture that is dominant in Kano, for example, he argues that historically, traditional rulers were given prime responsibility to manage and resolve disputes. Interestingly, the cases below will provide some evidence that traditional authorities, and in particular the Emir, continue to fulfil this role. However, at the same time, the cases will illustrate that the influence of these conflict resolution efforts varies greatly and was insufficient to stem the violence in 2004.

This may partly be due to the limitations of the conflict resolution approach to elite agency as a form of third-party intervention. Because in fact, many religious elites involved in conflict resolution are not external interveners to the field of contention that produces violence, but an inherent, authoritative, and often deeply partisan part of it. Perhaps reflecting this fact, Varshney (2002) builds on the notion of partisan leadership by arguing for the potential of inter-ethnic or inter-religious organisations (and leaders) to facilitate the prevention of inter-group violence. His argument is that inter-ethnic civil society leaders have better information, fewer prejudices, and inter-group biases and face no incentives to mobilise one group against the other; therefore, they are

\footnotetext{
${ }^{5}$ Weber (1978) defines charismatic authority as "the authority of the extraordinary and personal 'gift of grace' (charisma), the absolutely personal devotion and personal confidence in revelation, heroism, or other qualities of individual leadership".
} 
structurally less likely to facilitate violence and more likely to actively try to prevent it than intra-religious organisations and their leadership.

While this article identifies social mechanisms that are similar to Varshney's, it diverges by allowing intra-religious leaders to choose between discursive strategies that facilitate violence and those that facilitate non-violent collective action. This is not only a more realistic depiction of the choices facing religious leadership than the structural determinism implicit in Varshney's account, but it also avoids the somewhat tautological aspect of his argument that Brass (2003, p. 418) identified as "where there is peace, there is peace". It brings the analysis closer to more conventional theories of elite manipulation (Bates 1974; Chandra 2007; Collier et al. 2009) as well as to the Nigerian literature that focuses on the politicised agency of federal-level pastors and imams, such as the leaders of the Christian Association of Nigeria (CAN) or the Sultan of Sokoto (e.g. Hackett 2011). While these accounts sometimes struggle to present a convincing analysis of the connections between these high-level elites and their local followers, the present article concurs with the theoretical argument presented in these literatures: that religious leaders have a kind of discursive power, or influence over discursive framing processes, which they can use in a rather Janus-faced way not only to prevent but also to promote violence.

\section{Leadership and competition in Kano's religious marketplace}

To better understand these Janus-faced powers of religious leaders in Kano, however, we first need to consider the dynamics of religious contestation in the city. Metropolitan Kano is both the capital of Kano State and, arguably, the informal political and economic centre of northern Nigeria. The north-south division goes back to early colonial times, when Nigeria was ruled as separate Protectorates. After the Biafran Civil War, these regions lost their official institutional basis; however, they remained important ideas in political discourse. In terms of identity and ideology, northern Nigeria has historical roots in two pre-colonial Islamic state systems, the Sokoto Caliphate and the Borno Empire. Kano was an important Emirate in the Caliphate system and, arguably, the most important economic centre of the region-a position it has retained in post-colonial Nigeria. Moreover, even though the city has large communities of Christians, its politics today have revolved largely around Islamic political discourses. Most prominent among these has arguably been the notion of sharia, the Islamic system of law that has always been used to govern civil law but was re-extended as the criminal legal system in many northern states in 1999/2000 (Kendhammer 2016).

As noted above, Kano is a majority-Muslim city, but it is also the host to a wide range of Christian organisations. Given this range of groups, there are many positions that could qualify as 'religious leadership'. This article, however, is concerned only with those people who have the authority to preach to the members of their group. ${ }^{6}$ Such authorities in Kano's

\footnotetext{
${ }^{6}$ Northern Nigeria also has a range of 'traditional authorities' from the Sultan of Sokoto and Emir of Kano to the many local ward heads (mai unguwa) in neighbourhoods and villages. When these leaders act as Islamic preachers (imams) or even scholars, this article considers them as religious leaders. Analytically, however, the traditional Weberian aspect of their authority is distinct from the charismatic authority that allows them to perform as religious leaders.
} 
Muslim community can be divided into the Sufi brotherhoods (tariqa, pl.: turuq), reformist movements such as Izala ${ }^{7}$ and a wide range of Salafi and Wahhabi mosques, and the Jama'at Nasr al-Islam (JNI) and the Council of Ulama, the umbrella organisations for Islam in Nigeria. ${ }^{8}$ The Qadiriyya and Tijaniyya brotherhoods (turuq) are structured around the authority of a single leader (sheikh). ${ }^{9}$ Other groups have a more formal organisational structure, such as Izala that has a president (amir), a secretary, a treasurer, and modern accountancy practices. ${ }^{10}$

Christian leaders are organised in churches that differ in doctrine, rituals, social position, and membership (Ibrahim 2008; Mustapha and Ehrhardt, forthcoming). A basic distinction can be made between orthodox ${ }^{11}$ and charismatic churches: the former have formal organisational structures and are led by an executive council on the basis of a church constitution, ${ }^{12}$ while the latter are structured around the charismatic authority of prophets (Marshall 1995, p. 244). Note, however, that traditional orthodox churches, over time, have adopted beliefs and practices from charismatic churches as well as the other way around. ${ }^{13}$ Individual churches of both types are linked to Christian movements and organisations in Nigeria and abroad, through missions, sponsorship, and the education of their leaders. ${ }^{14}$ Collectively, churches in Kano also work together in the CAN, which represents the interests of Nigerian Christians in the political sphere and mirrors the Islamic claim for a universal umma. ${ }^{15}$

Almost by definition, the charismatic nature of the authority of preachers and religious scholars in Kano may be expected to facilitate their influence over the worldviews and discursive frames employed by their followers. But how extensive is this influence? One indication is contained in Table 1, which shows that religious leaders can count on considerable legitimacy in the eyes of the population: over $90 \%$ of the survey respondents profess to have some or considerable trust in religious scholars and clerics. This is likely representative of Kano's population at large, if not northern Nigeria generally. These numbers present a particularly stark contrast with the support for the police and politicians in the city, who can count on, at most, the trust of one third of the population.

A second reason to think that religious leaders have extensive influence over discursive framing lies in the intimate contact between them and their followers: this contact creates opportunities for the leaders to influence the way in which their followers think. In everyday life, Christian and Muslim preachers and scholars engage in various functions: enhancing spiritual welfare of their followers, providing basic

\footnotetext{
${ }^{7}$ Or in its full name, Jama't Izalat al Bid'a Wa Iqamat as Sunna (Society of Removal of Innovation and Reestablishment of the Sunna).

${ }^{8}$ For more detailed overviews of Islamic movements in northern Nigeria, see Abdussalam (2012), Alkali et al. (2012), Centre for Democratic Research and Training Mambayya House (2005a, b, c), Ibrahim (2012), Jimba (2012), Liman and Wakawa (2012), Medugu (2012), Modibbo (2012), Ndagi (2012), and Ostien (2012a, b).

${ }^{9}$ Interview with a Qadiriyya leader, 9 September 2006, in Kano.

${ }^{10}$ Interview with a professor of the Kano State Polytechnic, 10 August 2006, in Kano.

11 'Orthodox', here, denotes denominational churches, e.g. Protestant or Catholic, as opposed to charismatic and Evangelical churches.

${ }^{12}$ Interview with a reverend of the Evangelical Church of Christ in Nigeria (ECCN), 14 September 2006, in Kano.

${ }^{13}$ Interview with a priest of the Catholic Diocese of Kano, 9 September 2011, in Kano.

${ }^{14}$ Interview with a reverend of the ECCN, op. cit.

15 Ibid.
} 
Table 1 Proportions of respondents with at least some trust in political authorities

\begin{tabular}{lll}
\hline Political authorities & $\mathrm{N}$ & Percentage \\
\hline Political leaders & 375 & $28 \%$ \\
Police & 394 & $33 \%$ \\
Community leaders & 381 & $82 \%$ \\
Traditional rulers & 380 & $82 \%$ \\
Religious leaders & 398 & $93 \%$ \\
\hline
\end{tabular}

The table presents the perceptions survey (see note 3 for more details) results of the question: "On a scale from 1 (high trust) to 7 (no trust), how would you rate [authority]?". The percentages represent the proportions of respondents whose answers are in the range $1-4$

social services, representing the interests of their followers in society, and working to outcompete other religious groups (Ehrhardt 2012a). ${ }^{16}$ Given the absence, or prohibitively poor quality, of state-provided services, many of these functions are vital to many Nigerians. Providing them, however, requires a remarkable degree of intimacy in the contact between religious leaders and their followers. Not only do followers listen to the leaders' sermons, read their books, and ask them for advice on religious matters, but preachers and scholars also help their followers to care for their elderly family members, educate their children, and even enhance their marital (and conjugal) relations.

Together, high trust in religious leaders and the intimate interactions between religious leaders and their followers suggest that these leaders can have a considerable impact on what their followers think (their 'discursive frames'). At the same time, however, evidence from my fieldwork and the literature suggests at least three sets of constraints on religious leaders' agency in this regard. ${ }^{17}$ First, religious leaders are strongly dependent on the support of their followers. Not only does their reputation depend on the size of their followership, but their organisations also rely on tax-like contributions (e.g. tithes) from their followers. This means they have to be seen to provide real benefits to their communities, some of which may be spiritual but others tangible. More pertinently, however, it also means that the payoffs of fiery rhetoric must be weighed against the potential fallout to a leader's reputation: being deemed responsible for extensive collective violence has the risk of resulting in damage to one's public support.

Second, the competitive nature of Nigeria's religious market place strengthens the incentives for leaders to be seen 'to deliver'. Nigerian religion is big business (Nsehe 2016), with considerable returns to successful leaders and a continuous flow of innovative new entrants (Uchendu 2012); therefore, ambitious religious entrepreneurs face strong incentives to 'fragment' (Kane 2003) and compete with their former leaders, and other new contenders, for followership. What this competition means for constraints on discursive framing, however, is complicated. In the short run, fragmentation and competition make mainstream leaders more cautious in their rhetoric in order not to alienate their moderate followers or their political patrons; moreover, it has led religious organisations generally to provide a range of important social services.

\footnotetext{
16 Ibid.

${ }^{17}$ For detailed analyses of the functioning of the Izala, one of the most significant reformist Islamic groups in Northern Nigeria, and its leadership, see Loimeier (1997), Kane (2003), and Ben Amara (2011).
} 
However, it has also led more marginal leaders, supported by more radical constituencies, to take up increasingly polarised positions. The long-term effects of this complex dynamic are not yet clear-though if the past three decades of religious politicisation and polarisation in Nigeria are any indication (Ibrahim 1991), it may be that, in the longer run, intensifying competition pushes the entire spectrum of religious thought and rhetoric towards more extreme positions.

Third and finally, religious leaders are constrained by their relationship to politics and politicians. As Falola (1998, p. 2) writes, "religion is used by the power-hungry as a stepping-stone to power and political legitimacy" while, at the same time, "proponents of Christianity or Islam seek to unseat the rival religion, to impose their own values, and to control the state". The context of a patronage-oriented, oil-driven political system confronts religious leaders with difficult choices, particularly after the official re-extension of sharia law and, perhaps paradoxically, the reintroduction of electoral competition in 1999/2000 (Kendhammer 2016). On the one hand, many preachers and scholars feel that they need to distance themselves from politics in order to maintain their legitimacy; ${ }^{18}$ on the other, the reintroduction of sharia criminal law and its prominence in Kano State Government rhetoric has enticed many Islamic leaders to take up official functions in the state (Thurston 2015), even as it further marginalised Kano's Christian leaders politically. Formal politics thus plays an important role in constraining the actions of Kano's religious leaders, as do sectarian and interfaith competition, and the dependence of religious leaders on their followers. We will now turn to the case studies to see how these dynamics operate and interact in the production of violent riots and non-violent protests.

\section{Violence and non-violence in Kano: Plateau riots and cartoon protests}

Kano has a long history of violent riots, which can be traced back at least to the dynastic crisis of the Emirate in 1893. As Wakili (1997, p. 235; 2005, p. 45) shows, Kano experienced 11 large-scale riots between the crises of the Hausa-Igbo riots in 1953 and the Plateau riot in 2004; eight occurred in the second half of this period. This section will outline two cases of collective action in Kano, the Plateau riot on May 2004 and the peaceful cartoon protests on February 2006 and suggest explanations for why the first turned violent while the second did not. The central argument will be that while the Plateau riots were framed and organised using a discursive frame that identified local Christians as enemies, the cartoon protests were framed as a struggle between the religious city of Kano and the anti-religious west. This variation in interpretation was not inescapably caused by the qualities of the different triggering events. Rather, it is argued here that the agency of religious and political leaders, both on the Christian and Muslim sides, was pivotal in the production of these interpretive frames and, as such, instrumental to the development of collective violence in 2004 as well as to the prevention of violence in 2006.

Kano is host to several salient identity cleavages or fields of contention. As an indication of the range of cleavages that were salient in Kano in the mid-2000s, Table 2 presents the data from the perceptions survey on the salience of different social identities to individual respondents. It depicts, for every identity, the percentage of people who

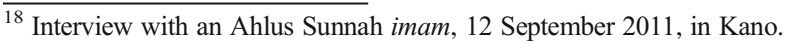


Table 2 Salient identities in Kano $(N=413)$

\begin{tabular}{ll}
\hline Identity & Percentage \\
\hline Religion & $94 \%$ \\
Ethnicity & $51 \%$ \\
Occupation & $40 \%$ \\
Gender & $36 \%$ \\
Neighbourhood & $31 \%$ \\
Nationality & $24 \%$ \\
State of origin & $7 \%$ \\
Political ideology & $2 \%$ \\
\hline
\end{tabular}

selected it as one of the three "most important to the way in which they think about themselves". ${ }^{19}$ The table shows the ranking in which religion and ethnicity ${ }^{20}$ are by far the most salient, followed by occupation, gender, neighbourhood, and at some distance, nationality, state of origin, and political ideology. If we accept the assumption that selfidentities are at least somewhat representative of salient cleavages, Table 2 gives us a broad outline of the repertoire of cleavages that were salient in Kano in the mid-2000s. ${ }^{21}$

For example, the salience of the state of origin likely indicates the tensions between Kano's indigenes, who can claim a primordial sense of belonging in the city, and the many immigrants who are considered non-indigenes (Harnischfeger 2004; Human Rights Watch 2006; Adebanwi 2009). Overlapping, but not equivalent, with this indigeneship cleavage is the field of inter-ethnic relations; in Kano, this covers a range of partly nested group distinctions, from the large regional wazobia cleavage (distinguishing the Hausa-Fulani, Yoruba, Igbo, and minorities) to the intricate and minute distinctions between families from different wards of Kano's old city (Ehrhardt 2012b). The Hausa-Fulani make up the majority of the city's population, particularly in the older neighbourhoods, but there are also many parts of the city with considerable numbers of non-Hausa residents, ranging from other northern groups such as the Kanuri to southern Nigerian Igbo and Ijaw.

The most salient of all cleavages and, therefore arguably, the easiest to activate and use as a discursive frame is religion (cf. Lewis and Bratten 2000; Afrobarometer 2015). Like ethnicity, though, religion covers a range of different cleavages rather than a single, uniform one. Within the Islamic community, for example, Kano has a long history of contestation between different Islamic groups: between the members of different Sufi brotherhoods (Paden 1973); between the Sufi brotherhoods and reformist Islamic movements, such as Izala (Loimeier 1997; Kane 2003; Amara 2011); between Izala and the more recent Salafi movements, such as Ahlus Sunna (Mustapha 2014);

\footnotetext{
${ }^{19}$ Respondents thus had the option of selecting up to three identities, which $93 \%$ of the respondents did ( $2 \%$ noted two and $5 \%$ only one).

${ }^{20}$ Because of the close relationship between ethnic groups and their language in the context of Nigeria, ethnicity and language have, for this analysis, been merged into a single communal identity. This is particularly pertinent in the case of Kano's majority Hausa-Fulani ethnicity, where Hausa as a language has facilitated the integration of the previously distinct Hausa and Fulani communities (cf. Paden 1973).

${ }^{21}$ One cleavage that is not covered in Table 2 but that is prominent in the literature in northern Nigeria is the status conflict between sarauta (aristocracy) and talakawa (commoners), the roots of which go back to the precolonial era and the late-colonial radical politics of Aminu Kano (Last 1967; an interview with a professor at Mambayya House, 9 August 2006, in Kano).
} 
and between 'mainstream' Muslims and the followers of jihadi groups such as Boko Haram (Last 2014). While all of these cleavages may be argued to have facilitated collective violence at different points of the city's history, the last one has done so most recently - and with devastating consequences (Amnesty International 2015b).

Much like their Islamic counterparts, Nigerian Christians also compete among each other over influence and followership. In Kano, orthodox Anglicans, Catholics, and Protestants struggle among each other as well as with the rapidly growing charismatic and non-denominational churches, indigenous African churches compete with those with roots outside the continent, and northern Nigerian Christians try to protect their membership and political influence against the enormously successful southern Nigerian settler churches (Ehrhardt and Ibrahim, forthcoming). At the same time, however, virtually all Christians in northern Nigeria share the status of being a minority in a Muslim-dominated society. This shared experience brings them together in pursuit of issues such as the right to proselytise or build churches and arguably increases the importance of ecumenical organisations such as the CAN. Moreover, it enhances the salience of another religious cleavage in Kano society: the contention between Muslims and Christians.

A lot has been written on the increasing polarisation of Nigeria's Christians and Muslims, the violence that has accompanied this polarisation, and the complicated intersections of this cleavage with ethnic differences, historical grievances, and horizontal inequalities (Ibrahim 1991; Falola 1998; Last 2007; Ehrhardt 2012b; Shankar 2014). In line with much of this literature, the first case study below illustrates one of the ways in which this cleavage can be used to mobilise for violence. The second case, however, shows that this dynamic is not unavoidable: where other Nigerian cities saw MuslimChristian violence in response to the cartoons of the Prophet Muhammad, Kano's leaders chose to mobilise people around yet another religious cleavage salient in the minds of their people: the distinction between the faithful Nigerians and the nonreligious Westerners. It was this rhetoric and its subsequent effects on mobilisation patterns, this article argues, that helped leaders prevent violence in 2006 where they had failed to do so in 2004.

\section{Revenge for Yelwa? The Plateau riots in May 2004}

On the 11th of May 2004, a peaceful demonstration in Kano transformed into violent riots, killing over 250 and wounding many more. These riots were initiated as a reaction to inter-group violence in Plateau State in central Nigeria earlier that month. As Human Rights Watch (2005, p. 1) documented, "on May 2 and 3, large numbers of well-armed Christians surrounded the town of Yelwa [in Plateau state] and killed around seven hundred Muslims". These killings in the restive Middle Belt region of Nigeria, compounded by the absence of state security forces, sparked an angry reaction in Kano that resulted in a violent riot on May 11. It therefore seems that this violence was triggered by external factors; however, the mechanisms through which this occurred betray the importance of many layers of local dynamics, including the grievances between Muslim 'natives' and Christian 'settlers'. The Plateau crisis was able to trigger violence, as it is argued here, at least partly because it was framed in terms of the local Muslim-Christian cleavage. This interpretation framed mobilisation and justifications as part of the struggle between native Muslims and settler Christians and hence made meaningful retaliation by Muslims against local Christians thinkable. 
Of course, much like other riots in the region (Cooper 2006), the Muslim-Christian dynamic is only one of the layers of meaning behind the violence. My point, therefore, is not that this was an exclusively Muslim-Christian riot; rather, it is to suggest that the Muslim-Christian frame allowed collective violence to occur in and around the demonstration against the Plateau violence. The riot began with a demonstration at a mosque in south-central Kano and ended two days later after the heavy-handed intervention of federal security forces. The demonstration was organised by the city's Council of Ulama with the aim of protesting against the killings in Plateau State and urging the government to intervene (Xinhua News Agency 2004). The ulama had officially requested permission from Kano Governor Shekarau, who himself was described to have actively denounced the Plateau violence and called for action from the Federal Government (Human Rights Watch 2005, pp. 57-58). An employee of the Kano Red Cross in 2004 told me how, in the run-up to the demonstration, he kept hearing news items and discussions of the Plateau killings on the radio and television and in the mosque. ${ }^{22}$ Similarly, in an interview with Human Rights Watch (2005, p. 58), Governor Shekarau estimated that $90 \%$ of mosque sermons in the days leading up to the demonstration were on the topic of the Plateau crisis.

The Plateau killings were thus a highly salient issue in the run-up to the 11 May demonstration, a fact that is reflected in the broad base of the coalition organising the demonstration. According to one interviewee, Islamic leaders from virtually all mainstream groups were involved. ${ }^{23}$ One of the pivotal people, by most accounts, was Sheikh Ibrahim Umar Kabo, a respected Tijani Islamic scholar who was chairman of the Kano Council of Ulama as well as Chairman of the Kano State Shariah Implementation Commission (Asoya 2004). Together with another Islamic scholar with a government position, Commissioner for Local Government and Community Development Alhaji Abdullahi Sani Rogo, Kabo was said to have led several thousand protesters in their march from the Zoo Road mosque to Government House, the seat of the Kano State Government. Moreover, he spoke at length to the protesters, denouncing the "genocide on the Muslim umma [that] has continued unaverted without caution from the Christian Association of Nigeria", but also preaching "Islamic brotherhood and love" and warning the protesters against violence (Asoya 2004; Ogbonnaya 2004). At the Government House, Kabo presented the governor with a letter outlining an ultimatum to the president: if the situation in Plateau was not resolved in seven days, the consequences would be his to bear (Human Rights Watch 2005, pp. 58-59).

Violence began towards the end of the demonstration, around noon. Like in many previous riots, it occurred mainly in areas with a mixed population (in ethnic and religious terms) or on the borders between homogeneous communities. For example, violence occurred in the relatively new and religiously mixed Brigade and Naibawa neighbourhoods as well as around the Bayero University Kano (BUK) and the Federal College of Education (FCE) campuses (Asoya 2004; Anthony 2004). All these areas host indigenes and nonindigenes, Hausa and non-Hausa, as well as Christians and Muslims. Surprisingly, the nonindigenous neighbourhood Sabon Gari was spared in this riot; on the basis of my interviews, it seems that Sabon Gari residents had barricaded and protected themselves, for example, by arming some of the neighbourhood residents with (home-made) guns. Even more surprising, however, was the prevalence of violence in the industrial areas of Sharada and Jaen.

\footnotetext{
${ }^{22}$ Interview with an employee of the Kano Red Cross, 16 August 2006, in Kano.

${ }^{23}$ Interview with a professor of the Kano State Polytechnic, op. cit.
} 
Before 2004, these neighbourhoods had never been plagued by riot violence. ${ }^{24}$ They are mostly industrial areas, with residential parts predominantly inhabited by native settlers, that is northern, often Muslim, Nigerians from rural Kano or other northern States.

Violence across neighbourhoods showed similarities in the ways it was executed. The majority of culprits belonged to the category of young men, aged generally between 15 and 30, and many of them were unemployed. Weapons used included machetes, smaller knives, an occasional home-made gun, and fuel-while weapons can be difficult to acquire, fuel is generally widely available in the jerry cans of the ubiquitous fuel hawkers. Cars and people were burnt in the street, and looting as well as killing occurred, supporting the view of multiple actors and motives; though some eyewitnesses held that looting was incidental to the killing (Human Rights Watch 2005, p. 60). One way in which victims were selected suggests the importance of the Christian-Muslim cleavage for some of the violence: they were chosen on the basis of their clothing, language, or accent or were asked to recite phrases from the Quran to prove they were Muslim (Human Rights Watch 2005, pp. 62-73). In some cases, this identification of victims was straightforward; for example, in Gyadi-Gyadi Court Road, the palace of the Eze Igbo, a traditional leader of the predominantly Christian Igbo community and hence an obvious target, was attacked. ${ }^{25}$ As one interviewee highlighted, however, victim identification was often an ambiguous process where ethnic and political dynamics interacted with religious ones:

In 2004, at the apex, [the violence] was more political, but when it comes down to the community level, it turned out to be religious or ethnic. Because in some cases the killings were along religious lines, and in others they were along tribal lines. [...] A pastor wearing a gown with a cap passed through gangs of youths, well-armed, and they were calling him "Baba", meaning daddy, "pass", while they were looking for Christians and he was a pastor... But they mistook him for a Muslim, with his gown and cap! And the person he was with was killed, instantly. Because he was wearing another tribe's clothes. So there you can see that it could be tribal. And if you go down-we had an interview with a village head [and] he rescued quite a number of non-Muslims in his house. He kept them there, he fed them, even though he is a Muslim... Only evacuating them was a problem. He had to bring them to the police station by night, at $2 \mathrm{AM}$, and the DPO [Divisional Police Officer] would bring the police van nearby, and then they would be taken to the police station. So at the community level it is sometimes religion, sometimes tribe, but the actual causes are political. ${ }^{26}$

The government reacted forcefully to the crisis in Kano by means of a shoot-on-sight order to the police (Civil Society 2004, p. 4). Many local newspapers credited the government for its "swift and decisive" action: while the initial dusk-to-dawn curfew on the 11th of May was ineffective, it appears that by the 13th, the military and police units had regained control over the rioters (Asoya 2004). Human Rights Watch (2005, pp. $73-$

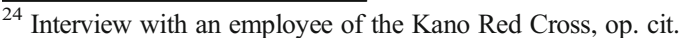

${ }^{25}$ Interview with a leading member of the Igbo Association Kano, 16 September 2006, in Kano.

${ }^{26}$ Interview with an employee of the Youth and Environmental Development Association (YEDA), 15 August 2006, in Kano.
} 
79), however, criticised the "brutal response of the police and the army" and its unprovoked extrajudicial killings. The respondent from the Kano Red Cross explained to me that this was a result of the many victims with gunshot wounds. For outside of Sabon Gari, he said, "I don't think many people had guns... [so] I don't know who shot all those people" ${ }^{27}$ In any case, on May 14, the violence had effectively ended, and on May 20, the citywide curfew was lifted. All in all, the riots resulted in at least 30,000 people, most of whom were Christians and non-indigenes, seeking refuge in one of the eight IDP camps around the Kano metropolis. ${ }^{28}$ Moreover, Human Rights Watch (2005, pp. 62-63) estimates that at least 250 people were killed and many more were wounded.

Why did this riot happen, and what was the role of religious leaders in its production? My findings suggest a twofold answer. In one sense, I have found no indication that religious leaders were directly implicated in organising the violence on May 2004. In fact, most religious leaders are quoted to have explicitly called on people to refrain from, or stop using, violent means at some point during this escalation. Rather, it seems that the riots were a 'perfect storm', a conjuncture of different dynamics and differently motivated perpetrators, rather than merely the result of elite manipulation.

The geography and nature of the most intense violence on May 11 and 12 sheds light on one of these dynamics behind this perfect storm: the economic grievances between the majority, the Hausa-Muslim population, and the often southern Nigerian immigrants in the Sharada industrial neighbourhoods. Although the former group constitutes the majority of residents both in the city and the neighbourhood, settlers take up most of the employment in the factories. It is a common understanding that this was one of the reasons unemployed Muslim youths chased and maimed the non-indigenous people who worked in the factories across from their place of residence. ${ }^{29}$ The economic grievance is therefore likely to have motivated some of the unemployed young men of Sharada and surrounding neighbourhoods to take the opportunity for revenge against their settler neighbours, through looting and direct physical violence. This economic dynamic was likely compounded by the fact that Jaen was one of the areas that received bodies of victims from the violence in Yelwa ${ }^{30}$ as well as over 500 refugees from the conflict in Plateau State (Human Rights Watch 2005, pp. 57-58). This no doubt contributed to the inflamed passions of the neighbourhood's residents, many of whom had family and friends in the Middle Belt.

Of course, there was also a political dynamic at play: both the Kano State Government and several of the interviewees have argued that in preparation for the demonstration on May 11, politicians mobilised their young supporters and paid them to destabilise the situation (Kazaure 2004, p. 2). ${ }^{31}$ This dynamic is part of a pattern of political competition

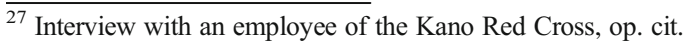

${ }^{28}$ Ibid.

${ }^{29}$ Interview with an employee of the YEDA, 9 August 2006, in Kano

${ }^{30}$ Interview with an employee of the YEDA, 15 August 2006, op. cit.

${ }^{31}$ Interviewees who mentioned this wished to remain fully anonymous. They did explain, however, why Kano politics created a structural incentive for such political mobilisation: first, because the fact that violent escalation of the demonstration would be a huge stain on the political slate of the incumbent governor, Shekarau, and second, because of the well-known tensions between Governor Shekarau (ANPP) and President Obasanjo (PDP). The competition between these two levels of the state, based on competing claims for jurisdiction and party political tensions, was expressed in the governor's refusal to heed the advice of the president and the police against the demonstration. In their public correspondence after the riots, the governor and the president underlined their differences in a mutual attempt to shift the blame onto each other (Obasanjo 2004; Shekarau 2004).
} 
that operates throughout Nigeria, in which political patrons hire local youths to be employed as 'thugs' (Gore and Pratten 2003; Smith 2004). Finally, all these dynamics interacted with the fact that local street youths took advantage of the disorder to settle personal scores or engage in looting. While there is considerable debate about the extent of the involvement of the Quranic students (almajirai) in riot violence (Hoechner 2013), it is likely that at least some of the groups of young men who 'hang out' in Kano's streets took the opportunity for mischief offered by the demonstration and subsequent riots (see also Casey 1998, 2008). In similar vein, some specific incidents of violence happening under the guise of the riots may have reflected personal tensions and grievances between community members and neighbours. $^{32}$

These dynamics are essential ingredients for explaining the 2004 violence; but religious leaders had little part to play in any of them. ${ }^{33}$ Their role was more subtle: I would argue they facilitated the violence by, first, framing the killings in Plateau State as part of Kano's Muslim-Christian cleavage and by, second, mobilising people for the demonstration. As for the first aspect, the patterns of mobilisation for the demonstration show how religious leaders actively framed the Yelwa killings in terms of the local tensions between Kano's native Muslims and settler Christians. Much of this mobilisation occurred in Kano's mosques, where imams preached against the injustices of Yelwa. Networks of Islamic religious ritual thus became vehicles of mass mobilisation and justification; Islamic leaders initiated and fostered the religious discourse through angry sermons (cf. Human Rights Watch 2005, p. 59). A young fuel hawker, who wanted to partake in the fighting but was kept at home by his family, told me how his imam explained it to him and his friends: "if a person kills three people, he who kills that person has avenged those three. In Islam, [...] this is good." ${ }^{34}$ Local and national media also reinforced this 'Muslims-versus-Christians' interpretation. Of course, there were leaders who cautioned against this rhetoric and the protest more generally; in particular, the Emir of Kano is said to have expressed misgivings to the governor. Governor Shekarau, however, allowed the demonstration to take place anyway, leading one of my respondents to argue that "usually, the problem is not from the Emirate; the problem mostly lies with the executives, the governor and the rest". 35

Nevertheless, by all accounts, Muslims and their leaders were angry because they felt 'their brothers and sisters' had been hurt (Ogbonnaya 2004). Islamic leaders denounced the killings in Yelwa because Muslims were killed and therefore presented the issue, as well as the protest, as part of the continuing struggle between Nigeria's Muslims and Christians. In the end, the brokerage of the ulama, for example through the persons of Sheikh Kabo and Alhaji Rogo, connected local mobilisation at the mosques into a larger protest movement of Muslims against the maltreatment of their brothers and sisters at the hands of Nigerian Christians. This brings us to the second aspect of the way in which religious leaders facilitated the 2004 violence: their role in the framing and organisation of the demonstration. A collective prayer session, in which tens of thousands of Muslims ritually reaffirm their collective religious identity, is a powerful bonding event even without a justification for collective anger; if this

\footnotetext{
32 Interview with an employee of the YEDA, 15 August 2006, op. cit.

${ }^{33}$ Interview with an employee of the YEDA, 15 August 2006, op. cit.; interview with a professor of the Kano State Polytechnic, op. cit.

${ }^{34}$ Interview with an anonymous fuel hawker, 15 August 2006, in Kano.

${ }^{35}$ Interview with an employee of the YEDA, 15 August 2006, op. cit.
} 
ritual is dedicated to and especially called in response to the suffering of fellow Muslims, such setting-based mobilisation has a huge mobilising and escalatory potential. The tone of the ultimatum to the president also supports this view, because its implicit threat is that of violence in Kano. In the words of a Muslim scholar and preacher:

...it is a revenge thing, it is a reaction. And if the reaction was not meant to be violent, they would not have called [the demonstration]. There are other ways in which you can take it calmly, and appease them. Why now call for a demonstration? Why now call for a prayer? [...] They knew they could not control it, nobody could. ${ }^{36}$

Of course, the violence began in a different part of the city from where the demonstration was held; but even so, I would follow the Muslim scholar quoted above in arguing that it was the demonstration that made the violence possible at that particular time, even if it does not by itself explain people's various motivations for violence. ${ }^{37}$ This is not to say that religious leaders intentionally facilitated violence; it may well be that "they miscalculated", believing that they could organise and control a mass demonstration, keeping it peaceful even as emotions ran so high. ${ }^{38}$ Either way, religious leaders were instrumental in creating an opportunity for violence along Christian-Muslim lines, not only by organising a mass demonstration but also by framing this demonstration in direct opposition to Nigerian Christians. Although the extent of this effect is difficult to estimate, a comparison of the 2004 riots with the nonviolent response to the 2006 cartoon crisis will help to illustrate its importance.

\section{"Why kill someone in Kano?" The cartoon protests on February 2006}

In the months following Kano's Plateau riots, several peace conferences were organised, of which the Kano Peace and Development Initiative (KAPEDI) Peace Forum held in September 2004 was arguably the most rigorous and most widely attended. Its analysis suggested three main strategies to prevent violence in the future: the creation of early-warning mechanisms, conflict resolution NGOs, and peace committees; capacity building and employment generation schemes for youths; and increased co-operation between non-indigenous ethnic leaders, traditional rulers, and the state government. It is difficult to assess the implementation and efficacy of these suggestions. It is clear, however, that by the time of my first fieldwork in 2006, the contention between local Muslims and Christians had not dissipated. Moreover, there is no indication that the inter-faith collaboration between religious leaders had increased; in fact, during my fieldwork, I encountered very little effective and sustained collaboration between Muslim and Christian leaders in Kano. I would argue, therefore, that Kano in 2006 still contained the same potential for violence as in 2004 even if it did not materialise in response to the cartoons of Prophet Muhammad in 2006.

\footnotetext{
${ }^{36}$ Interview with a professor of the Kano State Polytechnic, op. cit.

37 Ibid.

${ }^{38}$ Interview with a professor of the Federal College of Education, 10 September 2006, in Kano.
} 
Published in September 2005 in Denmark, it was only after the reprints of these infamous cartoons in other European countries that popular protest erupted in Pakistan, Syria, and other Muslim-majority countries (BBC 2007). In Nigeria, at least 15 people were killed and churches were burnt in Maiduguri, the capital of north-eastern Borno State (BBC 2006), which at the time was still considered as a largely peaceful backwater of Nigeria's restive north. The cartoons, therefore, clearly had the potential to trigger violence (Hackett 2011). But Kano, despite public and political fears, remained peaceful (Musa 2006). One of the reasons for this peace may have been the fact that the police and army were mobilised in advance of the demonstration in order to prevent violent 'hijacking' to occur. ${ }^{39}$ In addition, however, this paper argues that a second reason for Kano's successful management of the cartoon publication was the active attempt to frame the cartoons as an insult from secular foreigners to faithful Nigerians, rather than as an attempt by Nigerian Christians to vilify Nigerian Muslims. This framing allowed Christians and Muslims to mobilise together to take non-violent action against the people they considered the perpetrators: the 'godless' Danes.

A wide range of actors engaged in this framing, including religious leaders, politicians, news media, and even business elites. In Kano, both the Christian Association of Nigeria and Islamic authorities of all denominations denounced the Danish cartoons as an insult by the secular Danish state, rather than interpreting it as an inter-religious matter (BBC 2006; Musa 2006). The Emir of Kano went on the radio to urge people to remain calm; similarly, ulama went on the air telling people to refrain from violence and turn towards an economic boycott of Danish (and Dutch and Norwegian) products. ${ }^{40}$ Following this same framing discourse, members of the Kano State Assembly collectively burnt Danish and Norwegian flags in a protest against what they perceived as the transgressions of these countries (BBC 2006). Subsequently, the Kano State Assembly passed resolutions to cancel State contracts with Danish businesses, a move supported by newspapers (Daily Triumph 2006b), traders (Ibrahim and Marafa 2006), and business organisations (Daily Triumph 2006a). Moreover, in response to the Maiduguri violence, the Kano State Governor called the Islamic shura advisory body together, asking its imams to preach against violence ${ }^{41}$ and to lead their members in prayer against "the evil and provocative publications" from Denmark and Norway (Daily Triumph 2006c).

The respondent from the Kano State Red Cross also went on the radio to preach non-violence. "I personally went to Freedom Radio for an interview [...]. [I explained that there was] no need for destruction or killings: the person who did that is not in Kano, not even in Nigeria - so why kill someone in Kano?" On the basis of the interpretation of the cartoons as an insult by the secular Danes, Islamic leaders and the state government promoted a response that was targeted at the Danish economy, rather than at local Christians. Through sermons, radio appearances on Freedom Radio, newspaper articles, text messages, and emails, Islamic and traditional leaders and organisations rallied Kano residents to boycott Danish products (Kazaure 2006a, b). Unlike in 2004, existing grievances and tensions resulting from the Christian-Muslim competition were therefore not invoked as

\footnotetext{
$\overline{{ }^{39} \text { This proactive approach could }}$ be taken because President Obasanjo had one-sidedly ended his tensions with Governor Shekarau (cf. note 31) by threatening to enforce a state of emergency in any state where renewed violence would erupt - and hence end the political career of its incumbent governor.

${ }^{40}$ Interview with a professor of Mambayya House, op. cit.

41 Ibid.
} 
justifications for violent action, nor were the local Christian-Muslim identity boundaries activated. If anything, Muslims and Christians jointly protested against this insult of religion as a whole. Of course, because the insult had been directed at Islam, it is true that Islamic networks mobilised their members most strongly. But because Christian authorities like the CAN also denounced the cartoons, this mobilisation was inclusive of Christians and settlers at large. Brokerage therefore occurred across the local inter-faith divide rather than within both categories, deemphasising inter-group difference. As a result, the demonstration against the insulting cartoons failed to create an opportunity for violence.

This presents a stark contrast with the dynamics following the Yelwa violence, where a framing discourse based on the local Christian-Muslim cleavage facilitated violence that disproportionally victimised Christians and non-indigenes more generally. But there are also parallels between the cases, most importantly in the way in which political and religious leaders interacted. In both cases of mobilisation, political leaders and Islamic leaders worked closely together to frame, coordinate, and direct the public reaction. In 2004, the connection between political and religious leadership was embodied most explicitly by Sheikh Kabo and Alhaji Rogo: both were members of the Kano Council of Ulama as well as ministers in Governor Shekarau's government. In 2006, similarly, religious and political leaders worked together actively in order to organise public support for the economic response to the cartoon publications.

The connectedness of Islamic and political leadership in Kano is clearly not a new phenomenon, as political leaders have long used religion to bolster legitimacy even as religious leaders use politics for influence. But it seems likely that this pattern has been reinforced by the re-extension of criminal sharia law and the appointment of Muslim scholars to key positions in the Kano State Government (Thurston 2015). Moreover, it has become a deeply contested issue, both among Kano's politicians and among its Islamic leadership. In a country where politics is tainted by oil money and perceptions of corruption, many religious leaders claim to keep their distance from it; vice versa, the recent history of religiously framed violence in Nigeria has made religion one of the more volatile tools in the arsenal of politicians. This analysis, however, suggests that such divisions are often more rhetorical than real and that leaders who combine political and religious sources of power are perhaps most able to affect patterns of mobilisation and collective action.

Of course, both cases also demonstrated that Kano's politicians and state officials had important roles to play beyond their connections with religious authority. In fact, echoing Wilkinson's (2006) analysis of Indian riots, the cases suggest crucial roles for the state's security services. In 2004, their failure to prevent the riots was followed by strongly coercive measures, which, in themselves, likely contributed to the level of destructiveness of the riots. In 2006, in turn, the lack of an opportunity for violence was at least in part due to the preventive action taken by the federal security forces. ${ }^{42}$ Discursive framing, therefore, was by no means a sufficient condition to prevent violence in response to the cartoon publication; however, it was at least a contributing factor and, quite possibly, a necessary one.

${ }^{42}$ Ibid. 


\section{Conclusion: Janus-faced voices of authority}

This article has analysed the role of religious leaders in riots in Kano, the major urban hub in northern Nigeria. Its central argument has been that religious leaders in Kano can impact on violence and conflict resolution through discursive framing. Collective, inter-group violence often depends on discursive framing in the sense that members of one group need to justify their decision to target members of another group. This article has looked at two cases of collective action in Kano to highlight the effects of discursive frames on the nature of collective interactions: while the locally sensitive, grievance-ridden Muslim-Christian discourse helped to produce a deadly riot in 2004, a mere two years later, the inclusive frame juxtaposing the Danish people and all Kano residents allowed the city's Christians and Muslims to work together in a peaceful boycott against the Danes.

The exploratory nature of this article's methods implies that the findings are tentative and specific to Kano, ready for more extensive applications and testing but not (yet) generalisation. Yet they can have important implications. First, given that all large, diverse cities harbour a multitude of overlapping and intersecting identity cleavages, it is likely that in all these cities, some of cleavages can more easily be used to produce violence than others. This article has suggested that cleavages that are highly salient intersect with grievances and inequalities and allow people to identify local enemies facilitate violence more easily than cleavages without these features. As such, it builds on the social movements' literature that identifies framing as an independent variable explaining the outcome of violence (Snow 2004); also, it echoes Kendhammer's (2016) argument that the nature of democracy in northern Nigeria is affected by the way in which people think and speak about it. Further systematic research should test and expand on these findings in order to identify the effects of different rhetorical strategies and discursive frames on violent mobilisation. This would not only further our intellectual understanding of framing and collective violence but also offer clear implications for policy and political behaviour.

Second, this article has focused on the role of one set of political elites-religious leaders - in the process of discursive framing. Given the salience of religion, the legitimacy of religious leadership, and their intimate contact with followers, religious leaders were found to be influential in the selection and operationalisation of discursive frames to, publicly, make sense of external triggering events. By choosing and promoting one frame over others in the city's discursive repertoire, religious leaders thus contributed to both the exacerbation of collective violence and its prevention. This raises the important question of what determines the discursive choices that religious leaders make. This article has suggested pieces of an answer to this question, by highlighting both the constraints on the agency of northern Nigerian religious leaders that are inherent in their position and those constraints (and opportunities) that derive from the interminable connections between the region's political and religious spheres. Further research, however, should aim at putting these pieces together more systematically and analysing more fully how and why religious and political elites choose which discursive frames to employ in their public rhetoric (cf. Gopin 1997). After all, many Nigerian religious scholars and preachers are deeply concerned about the recurring violence in the north. Understanding what hinders, or helps, them in translating this concern into inclusive discursive framing is therefore an important next step towards the reduction of violence in the region. 
Open Access This article is distributed under the terms of the Creative Commons Attribution 4.0 International License (http://creativecommons.org/licenses/by/4.0/), which permits unrestricted use, distribution, and reproduction in any medium, provided you give appropriate credit to the original author(s) and the source, provide a link to the Creative Commons license, and indicate if changes were made.

\section{References}

Abdussalam, A. A. (2012). Muslims of Kwara State: a survey (NRN background papers). Oxford: Nigeria Research Network.

Adebanwi, W. (2009). Terror, territoriality and the struggle for indigeneity and citizenship in Northern Nigeria. Citizenship Studies, 13(4), 349-363. doi:10.1080/13621020903011096.

Afrobarometer. (2015). Summary of results: Afrobarometer round 6, Nigeria. http://afrobarometer. org/sites/default/files/publications/Summary\%20of\%20results/nig_r6_sor_en.pdf. Accessed 23 June 2016.

Alkali, A. (2009). 10 million kids beg in the north-minister. Leadership. Abuja. http://allafrica. com/stories/200911231395.html. Accessed 22 June 2016.

Alkali, M. N., Monguno, A. K., \& Mustafa, B. S. (2012). Overview of Islamic actors in northeastern Nigeria (NRN working papers). Oxford: Nigeria Research Network.

Allen, C. (1999). Warfare, endemic violence \& state collapse in Africa. Review of African Political Economy, 26(81), 367-384.

Amara, R. B. (2011). The Izala movement in Nigeria: its split, relationship to Sufis and perception of Shari'a re-implementation. (PhD Dissertation) Bayreuth International Graduate School of African Studies.

Amnesty International. (2015). Stars on their shoulders. Blood on their hands: war crimes committed by the Nigerian military. London: Amnesty International.

Anthony, T. (2004). How ethno-religious crisis again shattered Kano. Vanguard (May 16).

Asoya, S. (2004). Madness in the north. The News (May 24).

Bates, R. H. (1974). Ethnic competition and modernization in Contemporary Africa. Comparative Political Studies, 6(4), 457-484.

$B B C$ (2006). Nigeria cartoon protests kill 16. Web article. http://news.bbc.co.uk/2/hi/4728616.stm. Accessed 24 June 2016

$B B C$ (2007). Nigerian MP's burn Denmark's flag. Web article. http://news.bbc.co.uk/2/hi/africa/4689314.stm. Accessed 20 June 2016.

Bercovitch, J., \& Kadayifci-Orellana, A. S. (2009). Religion and mediation: the role of faith-based actors in international conflict resolution. International Negotiation, 14(1), 175-204.

Bercovitch, J., \& Rubin, J. Z. (2002). Studies in international mediation: essays in honour of Jeffrey Z. Rubin. Basingstoke: Palgrave Macmillan.

Berridge, G. (2002). Diplomacy: theory and practice. Basingstoke: Palgrave.

Blasphemy: Govt backs Assembly's resolution. (2006, September 2). Daily Triumph, pp. 1-2.

"Boycott of Danish products, others good development." (2006, February 22). Daily Triumph, p. 10. Kano.

Brass, P. R. (2003). The production of Hindu-Muslim violence in contemporary India, New Delhi. Oxford: Oxford University Press.

Brewer, J. D., Higgins, G. I., \& Teeney, F. (2014). Religion, civil society, and peace in Northern Ireland. Oxford: Oxford University Press.

Casey, C. (1998). Suffering and the Identification of Enemies in Northern Nigeria. Legal Anthropology Review, 21(1), 1-25.

Casey, C. (2008). "Marginal Muslims": Politics and the Perceptual Boundaries of Islamic Authenticity in Northern Nigeria. Africa Today, 54(3), 67-92.

Centre for Democratic Research and Training Mambayya House. (2005a). A directory of Islamic faith-based organisations in Northern Nigeria (p. 407). The Federal Government of Nigeria.

Centre for Democratic Research and Training Mambayya House. (2005b). Register of Islamic scholars in Northern Nigeria (p. 350). The Federal Government of Nigeria.

Centre for Democratic Research and Training Mambayya House. (2005c). Report on the Ulama in contemporary northern states of Nigeria (p. 184). The Federal Government of Nigeria.

Chandra, K. (2007). Why ethnic parties succeed: patronage and ethnic head counts in India. Cambridge University Press

Civil Society (2004). Kano sees red. 26, 3, p. 1. 
Collier, P., Hoeffler, A., \& Rohner, D. (2009). Beyond greed and grievance: feasibility and civil war. Oxford Economic Papers, 61(1), 1-27.

Cooper, B. M. (2006). Evangelical Christians in the Muslim Sahel. Bloomington: Indiana University Press.

Cruise O'Brien, D. B. (1975). Saints \& politicians: essays in the organisation of a Senegalese peasant society. London: Cambridge University Press.

Dahrendorf, R. (1958). Toward a theory of social conflict. The Journal of Conflict Resolution, 2(2), 170-183.

Daily Triumph (2006a) Boycott of Danish products, others good development (February 22). p. 10.

Daily Triumph (2006b). West's blasphemy against Islam (July 2). p. 6.

Daily Triumph (2006c) Blasphemy: Govt backs Assembly’s resolution (September 2). pp. 1-2.

Ehrhardt, D. (2012a). Religious leadership and governance in Kano. Survey (NRN working papers). Oxford: Nigeria Research Network.

Ehrhardt, D. (2012b). Struggling to belong: nativism, identities, and urban social relations in Kano and Amsterdam (D. Phil Thesis). University of Oxford.

Ehrhardt, D. and J. Ibrahim (forthcoming). 'The significant minority: Christians and Christianity in Northern Nigeria'. In Mustapha, R. A. and D. Ehrhardt (eds). Creed and grievance: Muslims, Christians and society in Northern Nigeria. Oxford: James Currey.

Falola, T. (1998). Violence in Nigeria: the crisis of religious politics and secular ideologies. Rochester: University of Rochester Press.

Fearon, J. D., \& Laitin, D. D. (2000). Violence and the social construction of ethnic identity. International Organization, 54(4), 845-877.

Gamson, W. A. (1992). Talking politics. Cambridge: Cambridge University Press.

Gamson, W. A., \& Meyer, D. S. (1996). Framing political opportunity. In D. McAdam, J. D. McCarthy, \& M. N. Zald (Eds.), Comparative perspectives on social movements: political opportunities, mobilizing structures, and cultural framings (pp. 275-290). Cambridge: Cambridge University Press.

Gentner, D., \& Stevens, A. L. (1983). Mental models. New York: Psychology.

George, A. L., \& Bennett, A. (2005). Case studies and theory development in the social sciences. Cambridge: MIT.

Gopin, M. (1997). Religion, violence, and conflict resolution. Peace \& Change, 22(1), 1-31.

Gore, C., \& Pratten, D. (2003). The politics of plunder: the rhetorics of order and disorder in Southern Nigeria. African Affairs, 102(407), 211-240.

Hackett, R. (2011). Nigeria's religious leaders in an age of radicalism and globalisation. In T. D. Sisk (Ed.), Between terror and tolerance: religious leaders, conflict, and peacemaking (pp. 123-144). Georgetown University Press.

Harnischfeger, J. (2004). Sharia and control over territory: conflicts between "settlers" and "indigenes" in Nigeria. African Affairs, 103, 431-452.

Haynes, P. J. (2009). Conflict, conflict resolution and peace-building: the role of religion in Mozambique, Nigeria and Cambodia. Commonwealth \& Comparative Politics, 47(1), 52-75.

Higazi, A. (2011). The Jos crisis: a recurrent Nigerian tragedy. Friedrich Ebert Stiftung.

Hirsi Ali, A. (2015). Islam is a religion of violence. https://foreignpolicy.com/2015/11/09/islam-is-a-religionof-violence-ayaan-hirsi-ali-debate-islamic-state/. Accessed 20 June 2016.

Hoechner, H. (2013). Traditional Quranic students (almajirai) in Nigeria: fair game for unfair accusations? In M.-A. Perouse de Montclos (Ed.), Islamism, politics, security and the state in Nigeria (pp. 63-84).

Horowitz, D. L. (2000). Ethnic groups in conflict. Berkeley: University of California Press.

Horowitz, D. L. (2002). The deadly ethnic riot. New Delhi: Oxford University Press.

Human Rights Watch. (2005). Revenge in the name of religion: the cycle of violence in Plateau and Kano States. New York: Human Rights Watch.

Human Rights Watch. (2006). They do not own this place: government discrimination against "nonindigenes" in Nigeria. New York: Human Rights Watch.

Human Rights Watch. (2013). World report 2013. New York: Human Rights Watch.

Human Rights Watch. (2014). World report 2014. New York: Human Rights Watch.

Human Rights Watch. (2015). World report 2015. New York: Human Rights Watch.

Ibrahim, J. (1991). Religion and political turbulence in Nigeria. Journal of Modern African Studies, 29, 115136.

Ibrahim, J. (2008). Christianity and democratic governance in Nigeria. Abuja: Unique Dimensions.

Ibrahim, U. K. M. (2012). Muslims of Benue State: a survey (NRN background papers). Oxford: Nigeria Research Network.

Ibrahim, S., \& Marafa, S. (2006, September 2). Kano traders boycott Danish, Norwegian products. Daily Triumph, pp. 1-2. 
International, A. (2015). Stars on their shoulders. Blood on their hands: war crimes committed by the Nigerian military. London: Amnesty International.

Jimba, M. M. (2012). Muslims of Kogi State: a survey (NRN background papers). Oxford: Nigeria Research Network.

Juergensmeyer, M. (2001). Terror in the mind of God: the global rise of religious violence. Oxford University Press.

Kane, O. (2003). Muslim modernity in postcolonial Nigeria: a study of the society for the removal of innovation and reinstatement of tradition. Boston: Brill.

Kazaure, M. U. (2004) Kano riots: evidence for involvement politicians. Daily Trust (May 13). p. 2.

Kazaure, M. U. (2006a). Muslims demonstrate in Kano against cartoon blasphemy. Abuja: Daily Trust.

Kazaure, M. U. (2006b). Kano government cancels contracts with Denmark. Abuja: Daily Trust.

Kendhammer, B. (2016). Muslims talking politics: framing Islam, democracy, and law in Northern Nigeria. Chicago: University of Chicago Press.

Kippenberg, H. G., \& McNeil, B. (2011). Violence as worship: religious wars in the age of globalization. Stanford: Stanford University Press.

Last, M. (1967). The Sokoto caliphate. London: Longmans.

Last, M. (2007). Muslims and Christians: an economy of political panic. The Round Table, 96(392), 605-616.

Last, M. (2014). From dissent to dissidence: the genesis \& development reformist Islamic groups in Northern Nigeria. In A. R. Mustapha (Ed.), Sects \& social disorder: Muslim identities \& conflict in Northern Nigeria (pp. 18-53). Woodbridge: James Currey.

Lewis, P. \& Bratten, M. (2000). Attitudes toward democracy and markets in Nigeria: report of a national opinion survey - January-February 2000. Washington D.C.: International Foundation for Election Systems.

Liman, S. H., \& Wakawa, A. S. I. (2012). Muslims of Nasarawa State: a survey (NRN background papers). Oxford: Nigeria Research Network.

Loimeier, R. (1997). Islamic reform and political change in Northern Nigeria. Evanston: Northwestern University Press.

Lukes, S. (2005). Power: a radical view. Basingstoke: Palgrave Macmillan.

Marshall, R. (1993). Power in the name of Jesus: social transformation and Pentecostalism in Western Nigeria revisited. In T. O. Ranger, O. Vaughan, \& A. H. M. Kirk-Greene (Eds.), Legitimacy and the state in twentieth-century Africa: essays in honour of A.H.M. Kirk-Greene (pp. 213-246). London: Macmillan Press.

Marshall, R. (1995). God is not a democrat. In P. Gifford (Ed.), The Christian churches and the democratisation of Africa (p. 301). Leiden: E.J. Brill.

McAdam, D., \& Tarrow, S. (2000). Nonviolence as contentious interaction. PS: Political Science and Politics, $33,149-154$.

Medugu, N. I. (2012). Muslims of the Federal Capital Territory: a survey (NRN background papers). Oxford: Nigeria Research Network.

Miall, H., Ramsbotham, O., \& Woodhouse, T. (1999). Contemporary conflict resolution: the prevention, management and transformations of deadly conflicts. Oxford: Polity.

Modibbo, M. S. A. (2012). Survey of Muslim groups in Plateau State of Nigeria (NRN background papers). Oxford: Nigeria Research Network.

Musa, N. (2006). At least 15 die in Nigeria cartoon protests (February 19). Associated Press Newswires. Retrieved from https://global-factiva-com.ezproxy.leidenuniv.nl:2443/redir/default.aspx?P=sa\&NS=16 \&AID=9LEI000700\&an=APRS000020060219e22j000az\&cat=a\&ep=ASI. Accessed 30 Aug 2016.

Mustapha, A. R. (Ed.). (2014). Sects \& social disorder: Muslim identities \& conflict in Northern Nigeria. Woodbridge: James Currey.

Mustapha, A. R., \& Ehrhardt, D. (Eds.). (forthcoming). Creed and grievance: Muslims, Christians and society in Northern Nigeria. Oxford: James Currey.

Ndagi, M. U. (2012). Muslims of Niger State: a survey (NRN background papers). Oxford: Nigeria Research Network.

North, D. C., Wallis, J. J., \& Weingast, B. R. (2009). Violence and social orders: a conceptual framework for interpreting recorded human history. New York: Cambridge University Press.

Nsehe, M. (2016). Wealthy Nigerians, pastors spend $\$ 225$ million on private jets. http://www.forbes. com/sites/mfonobongnsehe/2011/05/17/wealthy-nigerians-pastors-spend-225-million-on-private-jets/.

Obasanjo, O. (2004) Unrest in Kano. New Nigerian (May 19), p. 5.

Ogbonnaya, R. (2004). Killing in the name of religion. This Day (May 17).

Omeje, K. C. (2006). High stakes and stakeholders: oil conflict and security in Nigeria. Farnham: Ashgate Publishing, Ltd. 
Ostien, P. (2012a). A survey of the Muslims of Nigeria's north central geo-political zone (NRN working papers). Oxford: Nigeria Research Network.

Ostien, P. (2012b). Percentages by religion of the 1952 and 1963 populations of Nigeria's present 36 States (NRN background papers). Oxford: Nigeria Research Network.

Paden, J. N. (1973). Religion and political culture in Kano. Berkeley: University of California Press.

Paden, J. N. (2005). Muslim civic cultures and conflict resolution: the challenge of democratic federalism in Nigeria. Washington D.C.: The Brookings Institution.

Reimann, C. (2004). Assessing the state-of-the-art in conflict transformation. In Berghof handbook of conflict resolution. Berghof Research Centre for Constructive Conflict Management.

Shankar, S. (2014). Who shall enter paradise?: Christian origins in Muslim Northern Nigeria, c 1890-1975. Athens: Ohio University Press.

Shekarau, I. (2004) Re: Unrest in Kano. New Nigerian (May 19). p. 5.

Sisk, T. D. (2011). From terror to tolerance to coexistence in deeply divided societies. In T. D. Sisk (Ed.), Between terror and tolerance: religious leaders, conflict, and peacemaking (pp. 227-240). Georgetown University Press.

Smith, D. J. (2004). The Bakassi boys: vigilantism, violence, and political imagination in Nigeria. Cultural Anthropology, 19(3), 429-455.

Smock, D. R. (Ed.). (2006). Religious contributions to peacemaking: when religion brings peace, not war (vol. 55). http://www.usip.org/publications/religious-contributions-peacemaking-when-religion-bringspeace-not-war. Accessed 21 June 2016.

Snow, D. A. (2004). Framing processes, ideology, and discursive fields. In D. A. Snow, S. A. Soule, \& H. Kriesi (Eds.), The Blackwell companion to social movements (pp. 380-412). Oxford: Blackwell.

Stewart, F. (2008). Horizontal inequalities and conflict: understanding group violence in multiethnic societies. Basingstoke: Palgrave Macmillan.

Thurston, A. (2015). Muslim politics and shari'a in Kano State, Northern Nigeria. African Affairs, 114(454), 28-51.

Uchendu, E. (2012). New face of Islam in Eastern Nigeria and the Lake Chad Basin: essays in honour of Simon Ottenberg. Makurdi: Aboki.

United States Institute for Peace (USIP) (n.d.) Religion and peacebuilding. Website: http://www.usip. org/centers/religion-and-peacebuilding-glas. Accessed 22 June 2016.

Varshney, A. (2002). Ethnic conflict and civic life: Hindus and Muslims in India. New Delhi: Oxford University Press.

Varshney, A. (2007). Ethnicity and ethnic conflict. In S. C. Stokes (Ed.), The Oxford handbook of comparative politics (pp. 274-295). USA: Oxford University Press.

Wakili, H. (1997). The phenomenon of revolts and riots in Kano, 1893-1995: an historical perspective. Kano: Bayero University Kano.

Wakili, H. (2005). Youth and rioting in Kano, 1991-2004. FAIS Journal of Humanities, 3, $43-61$.

Weber, M. (1978 [1925]). Economy and society: an outline of interpretive sociology (vols. 1-2). Berkeley; London: University of California Press.

West's blasphemy against Islam. (2006, July 2). Daily Triumph, p. 6.

Wilkinson, S. I. (2006). Votes and violence: electoral competition and ethnic riots in India. Cambridge University Press.

Xinhua News Agency (2004). Update - Muslims protest central Nigeria town's massacre, demand Obasanjo's urgent action. Retrieved from https://global-factiva-com.ezproxy.leidenuniv.nl:2443/redir/default.aspx? $\mathrm{P}=\mathrm{sa} \& N S=16 \& A I D=9 L E I 000700 \& a n=X N E W S 00020040512 \mathrm{e} 05 \mathrm{~b} 0002 \mathrm{v} \& \mathrm{cat}=\mathrm{a} \& \mathrm{ep}=\mathrm{ASI} . \quad$ Accessed 25 Aug 2016 